\title{
ИЗМЕНЕНИЕ ФОРМ ОБРАЩЕНИЙ В РУССКОМ И КИТАЙСКОМ ЯЗЫКАХ В ХХ-ХХІ ВВ.
}

\section{CHANGES IN THE FORMS OF SALUTATIONS IN RUSSIAN AND CHINESE IN THE XX-XXI CENTURIES \\ Huang Shaofei}

Summary: This article examines the changes in the forms of Russian and Chinese salutations used in the dialogue between strangers, in the historical aspect (from the XX century to the present day) and the identification of factors that affect the changes in salutations in Russia and China. Analyzing the factors that influence changes in the forms of salutations, the author came to the conclusion that the evolution of salutations is closely related to the economic, cultural and political changes taking place in society and country.

Keywords: salutations, change, social change.
$\mathrm{O}$ бращение - это слово (или сочетание слов), называющее того, к кому (чему) обращаются с речью. Оно имеет форму именительного падежа и произносится с особой звательной интонацией [11]. Обращение, как лексический компонент коммуникативного акта, в процессе исторической изменчивости мира претерпело множество изменений, оставив нетронутым естественный процесс изменчивости лексики. Следовательно, социальные изменения оказывают влияние на язык. Как было отмечено американскими учеными, что язык, как социальное явление, сильно меняется по мере того, как социальная жизнь прогрессирует, когда происходит градиент или возбуждение социальной жизни.

Российско-китайские отношения характеризуются высокой динамикой развития и активными связями на всех уровнях, и теперь все больше и больше китайцев начинают изучать русский язык. Кроме того, в России китайский язык также указан в качестве одного из экзаменов по иностранному языку при поступлении в высшие учебные заведения. Язык является мостом общения между людьми, и обращение, как предвестник общения, занимает очень важное место в межкультурной коммуникации. Поэтому в данной работе будут рассмотрены изменения форм обращений в русском и китайском языках в XX-XXI вв. и будут выявлены факторы, влияющие на изменение форм обращений в русском и китайском языках. Это поможет учащимся, изучающим иностранные языки, понять культуру страны, В которой они изучают язык, чтобы лучше овладеть языком и достичь хороших коммуникативных целей в межкультурном взаимодействии.

\author{
Хуан Шаофэй \\ Аспирант, Московский государственный университет \\ имени М.В. Ломоносова \\ elisa666shaofei@yandex.ru
}

Аннотация: В данной статье рассматриваются изменения форм русских и китайских обращений, используемых в диалоге между незнакомыми людьми, в историческом аспекте (в период с XX в. до наших дней) и выявление факторов, влияющих на изменения обращений в России и Китае. Анализируя факторы, которые влияют на изменения форм обращений, автор пришёл к выводу, что эволюция обращений тесно связана с экономическими, культурными и политическими изменениями, происходящими в обществе и государстве.

Ключевые слова: обращение, изменение, социальные перемены.

\section{Россия}

XX век для России стал довольно насыщенным на события: Октябрьская революция 1917 года, которая привела к созданию нового государства; распад Советского Союза также привел к становлению нового государственного строя. Под влиянием таких серьезных социальных перемен обращение, как лексический компонент коммуникативного акта, также пережило существенные изменения.

\section{1. Октябрьская революшия 1917 года}

В царской России вопрос с обращениями обстоял довольно просто. Существовали обращения «господин» и «госпожа», различающиеся лишь по гендерной принадлежности, которые принято было применять при общении с людьми с высоким социальным статусом: выходцы высших сословий, богатые помещики и прочие обеспеченные люди. Помимо этого, существовали обращения «сударь» и «сударыня», а также «ваше превосходительство», «ваше благородие» и т.д. Использование данных обращений было признаком выражения уважения к представителям высшего класса.

После Октябрьской революции 1917 года в новой, социалистической России были уничтожены дворянство и помещичий класс. Особым законом отменяются все звания и чины. Исчезают обращения «сударь» и «сударыня» - все они были признаны унижающими достоинство человека. Обращение «господин» и «госпожа» пере- 
стали использоваться и, более того, осуждались новым равным обществом. Примером тому может послужить отрывок из повести М.А. Булгакова «Собачье сердце». События повести происходят в 20-е годы после Октябрьской революции. Главный герой, профессор хирургии, Преображенский в одной из неприятных бесед со своим «творением» Шариковым, сказал: «Я и доктор Борменталь будем называть вас «господин Шариков».

На что Шариков ему ответил: «Я не господин, все господа в Париже!».

В обиход граждан Советской России вошло обращение «товарищ», не имеющее цели гендерного или социального разграничения людей. Оно было введено с целью устранения разницы между мужчиной и женщиной, укоренения всеобщего равенства.

То есть в контексте социального развития и исторических перемен, идеология, представленная обращениями, также сильно изменяется. С ростом революционного движения в России в начале 20-го века слово «товарищ», как в свое время слово «гражданин», приобретает новый общественно-политический смысл: единомышленник, борющийся за интересы своего народа.

\section{2. Перио $\triangle$ СССР}

Интересным представляется тот факт, что с момента становления России как Страны Советов, процесс преобразования обращений так и не был завершен, хотя и претерпел существенные изменения. Причина в основном в том, что идеология, которую представляют старые и новые обращения, сильно отличается. Как было сказано выше, обращение «господин» было исключено из лексикона советских граждан. Борцы за новую страну, ярые коммунисты, считали тех, кто использовал по отношению к ним обращение «господа», врагами. В противовес этому, представители бывших высших сословий считали оскорбительным по отношению к себе обращение «товарищ», направленное на уравнивание всех.

Однако, со временем, обращение «товарищ» полностью вытеснило обращение «господин» из речи граждан Советского Союза. Это была страна товарищей.

\section{3. После распада Советского Союза}

В 1990-х гг. распад Советского Союза привел к значительным изменениям в российском обществе и его влияние на российский народ было беспрецедентным. Снова новое государство, новый строй, новые общественные устои. В таких условиях обращение снова претерпевает существенные изменения.

Советская культура и система обращений стали те- рять свои позиции. Начиная с конца 80-х гг. в деловом общении стали возрождаться такие обращения как «сударь», «сударыня», «господин», «госпожа». Снова столкнулись лицом к лицу обращения «господин» и «товарищ». Обращение «товарищ» понемногу стало выходить из обыденной речи людей. Его продолжают употреблять военные, члены партий коммунистического направления и люди для обозначения своих приятельских отношений.

Сфера применения обращения «господин» вновь стала расширяться. В последнее время данное обращение воспринимается как норма на заседаниях Государственной Думы ФС РФ, по телевидению, в деловой среде.

Интересное мнение касательно обращения «господин» выразил лингвист М. Кронгауз. Он отметил, что «обращение «господин» имеет разные характеристики использования в разные периоды:

1. В настоящее время «господин» можно использовать в сочетании со словами, обозначающими профессии, такие как «господин контролер», «господин проводник», «господин судья». До Октябрьской революции "господин" часто использовался с фамилиями, но не со словами, обозначающими род занятий. Например, “господин профессор, господин посол".

2. Сегодняшнее "господа" (множественное число) иногда может относиться не только к мужчинам, но и к присутствующим женщинам.

3. Раньше "господин" использовался как в письменной, так и в устной речи, а в настоящее время он обычно используется в письменной речи. В устной речи его употребление вызывает эффект отчуждения и может иметь даже негативный оттенок». [Кронгауз: 108-110]

Поэтому неуместно называть возвращение слова "господин" в сегодняшнем русском языке «возвращением», потому что сегодняшний "господин" не "господин" до Октябрьской революции, это просто видоизмененный товарищ. А мы, в свою очередь, перестав быть товарищами, так и не господами. [Кронгауз: 143].

В деловой сфере, в особенности среди преподавателей и юристов, распространенными стало обращение «коллега». Например, «Дорогие коллеги», «Уважаемые коллеги».

С распадом Советского Союза в обращения вернулась некая гендерность. Половая принадлежность стала снова очень важна. По отношению к незнакомым молодым девушкам стало широко использоваться выражение «барышня». Как правило, данное обращение относится к «девочкам в приличных и элегантных платьях в возрасте от пятнадцати до шести лет», и используется 
представителями пожилого возраста. Распространенными как среди молодежи, так и среди людей среднего и пожилого возраста стали обращения «ребята», «девчата», «девчонки». Например: «Не стесняйтесь вы меня, девчата, правду говорите, ради Христа. Не прощу себе, если покалечитесь». (Б.Л.Васильев)

По отношению к мужчинам и женщинам среднего и пожилого возраста обращения практически не изменились: «мужчина», «женщина», «гражданин», «гражданка». Однако, по мнению многих, обращения «мужчина» и «женщина» является нарушением речевого этикета и проявлением невоспитанности. Они могут восприниматься адресатом как неуважение к нему, даже оскорбление. В таком случае предпочтительнее начинать разговор без обращений, используя обезличенные формы: «Будьте добры...», «Простите...», «Вы не скажете...», «Скажите, пожалуйста...», «извините», «будьте добры» и другие.

\section{Китай}

Для Китая XX век стал не менее насыщенным на исторические события, чем для России: Создание Китайской Народной Республики, Культурная революция, проведение политики реформ и открытости. Под влиянием таких серьезных исторических и социальных перемен китайский язык также прошел три периода изменений и обращения, в рамках речевого этикета, не стали исключением.

\section{1. Становление Китайской Народной Республики}

В 1949 было провозглашено о создании Китайской Народной Республики. Основой нового государства стало построение коммунизма и всеобщее равенство. Итогом таких государственных преобразований стало введение в качестве обращения слова “同志” [тонджи] - «товарищ». Обращение "同志" [тонджи] - «товарищ» берёт свое начало из Советского Союза, ставшего единомышленником КНР в первые годы её становления. В результате интеграционного влияния идеологии правящей партии, с одной стороны, уменьшилась дифференциация между различными группами общества, быстро установились общечеловеческие «товарищеские» отношения, а с другой стороны, стали применяться политические средства для очищения идеологической культуры от влияния феодализма и капитализма. Целью нового государства явилось желание сделать культуру члена нового коммунистического общества высоко идеологизированной социалистической культурой.

В Китае обращение “同志” [тонджи]-«товарищ» с явным политическим оттенком распространилось среди широких масс и между людьми исчезли классовые и гендерные различия. При встрече, не только солдаты, рабочие, фермеры, интеллектуалы, но и незнакомцы на- зывали друг друга «товарищами».

Помимо обращения “同志"«товарищ», широко распространено было обращение "师傅" [шифу] - «мастер», которое, в основном, употреблялось при обращении к представителям физического труда. Обращение “同志” «товарищ» стало широко употребляемым и могло использоваться и при обращении к представителям физического труда (продавцы, водители и владельцы лавок), и при обращении к интеллектуальным и общественным лидерам.

\section{2. Периол Культурной революшии}

1960-70-е гг. в Китае ознаменованы свершением Культурной революции. Данное событие повлекло существенные изменения в речевом этикете, в том числе в обращениях. Своего рода опале подверглось обращение «товарищ» в политическом смысле. В различных материалах СМИ (газеты, журналы) любое лицо, называемое «товарищем», объектом осуждения и объявляется практически врагом. Использовать обращение «товарищ» стало небезопасно, в отличии от обращения “师傅” «мастер», которое стало широко использоваться, заменив «товарища».

\section{3. Перио $\Delta$ политики реформ и открытости}

С 1978 г. в Китае начал свой старт политики реформ и открытости. В процессе всеобще глобализации отношения между странами стали весьма тесными и открытыми. Это повлияло на прежние культурные традиции и ценности Китая. В обиходную речь стали возвращаться забытые обращения, что разнообразило набор социальных обращений. На смену устаревшим «товарищ» и «мастер» пришли такие обращения, как “先生"[сяньшэн] - «господин», “女士"[нюйши] - «дама», “小姐”[сяоцзе] «мисс». Обрели популярность такие обращения, как “老 板"[лаобань] - «босс», “经理”[цзинли] - «менеджер», “董事 长”[доншичжан] - «президент», “主席”[чжуси] - «председатель» и т. д.;

Новые политические веяния стали отправной точкой для создания новых обращений, отражающих некоторые внешние качества человека. Появились такие выражения, как “美女”[мэйнюй] - «красивая женщина», "I巾 哥” [шуайгэ] - «красивый парень», “郬女” [ляннюй] - «красивая девушка», “大叔” [дашу] - «мужчина средних лет». Следует отметить, что «красивая девушка» не обязательно красива, а «красивый парень» Следует отметить, что «красивая девушка» не обязательно красива, а «красивый парень» не имеют комплиментарного характера. Их цель - сократить дистанцию при общении.

Популярностью пользуются и обращения, отражающие симпатию и любезность по отношению к молодым 
людям, которых мы считаем красивыми, например: “小 哥哥”[сяогэгэ] - «младший брат», “小姐姐”[сяоцзецзе] «младшая сестра».

По мере развития общества некоторые общепринятые обращения постепенно приобретают новые значения. Например, термин “同志” также означает «гомосексуализм». Многие гомосексуалисты привыкли называть «товарищами». Использование данного обращения среди представителей нетрадиционной сексуальной ориентации популяризировалось в конце 1980-х годов в Гонконге, а в середине и конце 1990-х годов постепенно распространилось на внутренний континент через провинцию Гуандун.

Однако обращение“同志" «товарищ», в традиционном понимании, по-прежнему используется в определенной области. Фактически, данное обращение по-прежнему используется среди граждан (особенно пожилых людей). Например, в автобусах молодые люди часто называют водителей “叔叔”»дядей», “师傅”»мастером» и т. д., в то время как пожилые люди, в особенности рожденные в 50-х гг. XX в. по привычке называют водителей “同 志"«товарищами».

В современном китайском письменном языке слово “同志” «товарищ» также часто используется в качестве обращения в традиционном смысле. Например, в ходе проведения ежегодной государственной китайской конференции «Две конференции» обращение «товарищ» по прежнему пользуется популярностью в ходе общения между участниками.

Но стоит отметить, что в Китае, как и в России, в рамках современного речевого этикета, предпочтительнее использование обезличенных обращений “麻烦问一下” 、“请问”, в целях соблюдения нейтральности речи и выражения уважения к собеседнику.

Из приведенного выше анализа можно сделать следующие выводы:

\section{1. ВАияние экономической среды на обрашение}

Экономический фактор как фундаментальный стимул социального развития имеет решающее значение для изменение семантики обращений. В разные годы в связи с социальными, историческими и экономическими изменениями, возникают новые социальные отношения. Это приводит к появлению новых смыслов в общепринятых обращениях, что позволяет нам косвенно отследить процесс этих изменений.

После проведения политики реформ и открытости китайская социально-экономическая жизнь стала стремительно меняться. Отношения между людьми посте- пенно диверсифицировались, обращения претерпели изменения. “同志” [тонджи]-«товарищ» был заменен обращениями “小姐"[сяоцзе]-«мисс» и “先生”[сяньшэн]«мистер» на всей территории Китая и больше в обиходе не используется.

Данные изменения в системе обращений отражают социальные изменения, происходящие в обществе в связи со стремительным развитием экономики.

\section{2. Влияние культурной среды на обрашение}

Культура играет важную роль в процессе эволюции обращений. И любая культура проходит процесс взаимодействия с иными культурами, что влечет некоторые поглощения культурных традиций, их изменения.

Примером тому служит тот факт, что в последнее время в китайском языке появилось очень много заимствованных слов, в том числе и среди обращений. В процессе глобализации в китайском языке отмечается большое количество заимствований, в том числе и среди обращений. Например: “白领”[байлин]»белый воротничок», CEO «генеральный директор».

Интерес представляет история слова “同志” «товарищ». Слово “同志” «товарищ» в китайском языке существует уже 2 тысяч лет. Но обращение “同志" «товарищ», касательно представителей нетрадиционной сексуальной ориентации, не имеет исторической подоплёки. Изначально, обращение “同志” «товарищ» касательно гомосексуалистов стало популярным в Гонконге. После возвращения Гонконга в состав Китайской Народной Республики, культурный обмен между этими двумя территориями продолжал углубляться, и эта социальная проблема, которая уже очень распространена на Западе, официально вошла в наше видение Китая. Отсюда видно, что эволюция значения обращения “同志" «товарищ» отражает коммуникативную конвергенцию различных культурных форм общества.

\section{3. В^ияние политической среды на обрашения}

На протяжении всей истории влияние политического фактора на выражение обращения, как лексический компонент коммуникативного акта, было минимальным. Но в определенные периоды политическая жизнь сыграла решающую роль в преобразовании обращений. Типичным примером является обращение “同志" «товарищи» в период культурной революции, когда данное обращение имело политическую окраску. В современном китайском обществе слово “同志" «товарищ», как традиционное обращение, по-прежнему широко используется в Китае, что также связано с политическим фактором в Китае. Пропаганда использования слова “同志" «товарищ» в партии не по званию, является хорошей традицией 
Коммунистической партии Китая. На сегодняшний день в ведущих отечественных СМИ, на официальных встречах, обращение "同志" «товарищ» по-прежнему остается довольно популярным.

В русском языке обращение «товарищ» изначально применялось к людям, исполняющими одно дело, связанных общими условиями жизни и обстоятельствами. Лишь в XX веке, в период революционных волнений, слово товарищ получило политическую окраску, распространившись в качестве обращения в среде коммунистов, социалистов и т. д. Использование обращения «товарищ» призвано подчеркнуть солидарность и взаимное доверие идеологических единомышленников.

Проведенное исследование показало, что социальные изменения оказывают влияние на язык и речевой этикет, неотъемлемой частью которого являются обращения. Эволюция обращений тесно связана с экономическими, культурными и политическими изменениями общества и государства.

\section{ЛИТЕРАТУРА}

1. Хуан Бижон. Анализ мотивов и причин изменения на употребление обращений. -Пекин: 2009.

2. Лю Гуанчжунь. Восприятие перемена общества сквозь призму изменения фразеологии. -Пекин: 2001 (4).

3. Кронгауз М. Русский язык на грани нервного срыва. -М.: Языки славянской культуры, 2008.

4. Балакай А.Г. 0 русских обращениях [J]. Русская речь, 2005 (6).

5. Формановская Н.М. Русский речевой этикет: лингвистический и методические аспекты [М] .М.:Изд. ЛКИ, 2008.

6. 钟尹，汉语称谓语的变化及其语用特点 $[M]$ ，北京，新华出版社，2005. (Чжун Инь. Изменение китайских обращений и их прагматические особенности . -Пекин: (иньхуа, 2005.).

7. 李树新，现代汉语称谓词与中国传统文化[M]，北京，北京大学出版社，1990. (Ли Шусинь. современное китайское название и традиционная китайская культура. -Пекин: Пекинского университета, 1990.).

8. 杨永林， 《社会语言学研究：功能? 称谓? 性别篇》，上海，上海外语教育出，2004. (Ян Юнлинь. Социолингвистические исследования: функции? Обращение? Пол? «. -Шанхай : Образование иностранных языков в Шанхае, 2004.).

9. 王枫，李树新，同志称谓的历史嬗变及其语义特征内蒙古大学学报（人文·社会科学版），2005. (Ван Фэн, Ли Шусинь. Историческая трансмутация и семантические особенности обращения “同志". -Внутренния Монголия: журнал Внутренней Монголии (издание гуманитарных и социальных наук), 2005.).

10. 金采薇，党内应该称“同志”，《人民日报》，1998年9月4日. (Цзинь Цайвэй. В партии должен обращаться на“同志”. - Жэньминь жибао, 4 сентября 1998 года.).

11. Русская грамматика. Том П. Синтаксис. М.: «Наука», 1980

(c) Хуан Шаофэй (elisa666shaofei@yandex.ru). 